\title{
Importance of food plants in the prevention and treatment of diabetes in Cameroon
}

\author{
Nole Tsabang1, Lionel W. Tsambang Djeufack², Clément G. Yedjou ${ }^{3}$ and Paul B. \\ Tchounwou $^{4}$
}

${ }^{1}$ Independent Consultant (Ex researcher of the Institute of Medical Researches and Medicinal Plants Studies (IMPM), Visiting lecturer at the University of Yaoundé I, Faculty of Medicine of Biomedical Science, at the University of Dschang, Faculty of Animal Biology and at the High Institute of Environmental Science, Yaounde-Cameroon; ${ }^{2}$ Medical Doctor, Centre cardiologique Médicale, Po Box 13576 Yaounde, Cameroon; ${ }^{3}$ Cellomics and Toxicogenomics Research Laboratory, NIH-RCMI Center for Environmental Health, Jackson State University, Jackson, USA; ${ }^{4}$ Molecular Toxicology Research Laboratory, NIH-Center for Environmental Health, College of Science, Engineering and Technology, Jackson State University, 1400 Lynch Street, P.O. Box 18540, Jackson, Mississippi, USA

Corresponding Author: Tsabang Nole, PhD. Independent of Ethnopharmacology and Traditional Medicine, Department Pharmacology, Yaounde Cameroon consultant Visting lecturer of Traditional Medicine, Department of Traditional Medicine and Pharmacology, Yaounde Cameroon

Submission date: September $4^{\text {th }}, 2018$, Acceptance Date: February $25^{\text {th }}, 2019$, Publication Date: February $28^{\text {th }}, 2019$

Citation: Tsabang N., Djeufack L.W.T., Yedjou C.G., Tchounwou P.B. Importance of food plants in the prevention and treatment of diabetes in Cameroon. Bioactive Compounds in Health and Disease 2019; 2(2): 11-26. DOI: https://doi.org/10.31989/bchd.v2i2.554

\begin{abstract}
Background: Diabetes is a metabolic pathology that affects the human body's capacity to adequately produce and use insulin. Type 1 (insulin-dependent) diabetes accounts for 5-10\% of diabetic patients. In Type 2 diabetes the insulin produced by the pancreatic islets is not properly used by cells due to insulin resistance. Gestational diabetes sometimes occurs in pregnant women and affects about $18 \%$ of all pregnancies.

Diabetes is one of the most important multifactorial metabolic chronic diseases with fatal complications. According to the International Diabetes Federation's estimations in 2015, 415 million people had diabetes and there will be an increase to 642 million people by 2040 . Although many ethnopharmacological surveys have been carried out in several parts of the world, no ethnomedical and ethnopharmacological surveys have been done to identify plants used for the prevention and treatment of diabetes.
\end{abstract}

Objective: This study aimed to collect and document information on food plants' remedies consumed for the prevention and treatment of diabetes in Cameroon 
Methods: Ethnomedical and ethnopharmacological thorough preparations were conducted with 1131 interviewees from 58 tribes, following a random distribution. Diabetic patients recorded among this sample signed the informed consent and allowed us to evaluate the effectiveness of 10 identified food plants usually used for self-medication. They were divided into two groups: Group 1 comprised of 42 diabetic patients who regularly consume certain of these food plants, and Group 2 included 58 patients who were town-dwellers and did not regularly eat these identified food plants.

Results: It was recorded that the onset of diabetes in patients were at about 70 years and 45 years for Group 1 and Group 2 respectively. Hence, a relationship was demonstrated between the onset of diabetes and the consumption of food plants. They contributed to the prevention and/or the delay in clinical manifestations.

Conclusion: Further investigations and/or clinical trials involving a large number of both type 1 and type 2 diabetics are needed to describe the therapeutic action of many food plants against diabetes. However, this study provides scientific support for the use of herbal medicines in the management of diabetes.

Keywords: Cameroon, food plants, diabetes, prevention and treatment

\section{INTRODUCTION}

\section{Prevalence of Diabetes in Cameroon}

Diabetes is a quite common chronic disorder among the Cameroonian population (1). Indeed, epidemiological studies using standardized methods show that at least $10 \%$ of the Cameroonian population has diabetes. About $90 \%$ of people with diabetes are type 2 (noninsulin dependent [2].

It is a real and crucial health problem in Cameroon which rapidly financially suffocates the affected families. In Cameroon, as in the world, there are convincing evidences of reduced risk of diabetes for both physically active adults who maintain a normal body mass index (BMI) during adulthood and for overweight adults with reduced tolerance to glucose that are voluntarily losing weight [2]. Overweight, obesity, abdominal obesity, physical inactivity and maternal diabetes are increased risks for developing type 2 diabetes [2].

\section{Classification and diagnosis}

Undiagnosed diabetic patients constitute a significant part of Cameroon disease population. Epidemiological studies must be conducted by screening in the target population. Without this systematic testing, an incomplete and potentially misleading image of the frequency or distribution of the disease is still persisting in Cameroon [1].

The slow and persistent signs that include polyuria, polyphagia, and polydipsia do not call to attention the unconscious patients towards their mobilization to health centers. It is faced with complications that patients go to the hospital where the diagnosis is really made. For many indigenous people, diabetes is a mystic disease. For this reason, it may be well treated by local therapists. Furthermore, patients in a difficult socio-economic context are only treated by local therapists. Far from towns, many of them die without being diagnosed [3-4]. 


\section{Treatment in Cameroon}

In Africa and particularly in Cameroon, the poor populations, faced with the high increasing prevalence of diabetes, have developed the use of medicinal plants to try to overcome this pathology and its complications [5]. Care for uncomplicated diabetes can be integrated into primary health care conducted by nurses. Centers for diabetics' health care and for dialysis exist in reference hospitals where patients' admission is possible. However, this conventional treatment is still restricted to the wealthy class.

\section{Importance of food}

One of Cameroon's greatest challenges is to produce a sufficient and healthy variety of food for its populations. The production of this food must ensure environmental integrity, economic self-reliance and social wellbeing [6]. What we eat is critical to our health. Far from merely providing our body with nutrients, the food also provides minerals, vitamins, and various bioactive substances. It promotes the synthesis of hormones and enzymes. Food helps the body to fight against attacks from the outside by strengthening the immune system. With regard to diabetes, it is the excess of glucose that must be metabolized by a complex regulatory system, centered on three elements: the kidneys, the storage organs (liver and muscles), and the neuroendocrinal mechanism.

\section{Kidneys}

This organ filters glucose through the glomeruli to reabsorb it through the tubules. Above a maximum value of $0.20 \mathrm{~g}$ reabsorbed sugar per minute, the renal tubules reject the excess through urine [7].

\section{Association between Diabetes Mellitus and chronic renal failure and the pathogenesis of diabetic nephropathy.}

Diabetic nephropathy and associated kidney disease remain an unavoidable major burden to the health systems in developed and developing countries and also to people with diabetes and non-diabetic individuals and their families. It is likely that the pathophysiology of diabetic nephropathy involves a multifactorial interaction between metabolic factors including glucosedependent pathways, such as finished products of advanced glycation and their receptors. It also involves hemodynamic factors like various vasoactive hormones, such as components of the renin system - angiotensin. These factors contribute to the pathological damage of the glomerulus and tubulointerstitium [8].

End-stage renal failure is a condition in which the kidneys are no longer able to function properly to meet the daily metabolic needs. This affliction usually occurs as a result of chronic kidney failure. A study conducted in Khuzestan, Iran, found that diabetes was the most common cause of chronic Kidney failure. Only $10 \%$ of cases were due to Glomerulonephritis. [4]. Kidney disease increases the need for insulin in diabetic patients. In diabetics with chronic renal failure, accumulation of uremic toxins and increased levels of parathyroid hormone are responsible for insulin resistance in particularly skeletal muscle tissue. This complication disrupts glucose metabolism and glycogen production. Other metabolisms including Metabolic acidosis, elevated levels of parathyroid hormone and decreased vitamin D levels, provoke the 
reduction of insulin secretion in patients with kidney disease $[9,10]$. Oxidative stress plays a critical role in the expansion of diabetic chronic renal failure $(11,12)$. The morphologic distinctiveness of diabetic nephropathy consist of tubular atrophy, glomerular hypertrophy, arteriolar thickening, basement membrane thickening, mesangial expansion, and interstitial fibrosis, which are amongst the microvascular complications of diabetes [13]. Up to date researches have determined that both high glucose-induced changes in antioxidant function and high glucose-induced cellular reactive oxygen species production contribute to the diabetes induction of renal failure $[14,15]$

\section{Storage organs}

In the liver glucose is converted into glycogen and stored, which serves as an emergency carbohydrate reserve. The muscles produce fat reserves following the conversion of glucose into lipid.

\section{Neuroendocrine system of charge and discharge}

The storage and burning of glucose together with hyperglycemia and hypoglycemia are reversible through a self-regulatory process involving the nervous system and the endocrine system. The hypothalamus below the brain is sensitive to lowering blood glucose and it sends impulses to the pituitary gland that produces the somatotropic hormone and stimulates the endocrine system. Two antagonistic hormonal systems regulate glycemia. The hypoglycemic system limited to a single hormone: insulin, produced by beta cells grouped in islets of Langerhans in the endocrine pancreas. The hyperglycemic system consists of several hormones, the most important of which are:

Glucagon, which is the hormone produced by the islet cells of Langerhans, which raises blood glucose by increasing the rate of release of glycogen by the liver,

The thyroid hormone thyroxine, which is released without the influence of pituitary thyreostimulin and which accelerates the intestinal absorption of carbohydrates and facilitates the release of glucose from the liver and the conversion of lipids and proteins into glucose (neoglycogenesis)

Growth hormone or somatotropic hormone inhibits the burning of sugars by inactivating the action of insulin on hexokinase, facilitates neoglycogenesis and enhances glucagon synthesis;

Corticosteroid hormone, or glucocorticoid hormone called cortisone, secreted under the influence of ACTH (adrenocorticotrophic hormone or pituitary corticostimiline), acts by inhibiting insulin at the level of phosphorylation and amplifies neoglycogenesis The adrenal medulla hormone (adrenaline secreted under the influence of the sympathetic nervous system, intervenes urgently when the blood glucose drops to around $0.50 \mathrm{~g}$ p. 1000 by causing a glucose flow of the liver reserve $[16,17]$. 
All these hyperglycemic hormones are counterbalanced by insulin, the only hypoglycemic hormone. It is the disruption of glycoregulation that is responsible for diabetes, a condition in which insulin becomes insufficient, totally absent or resistant to cells. In view of the role of insulin in this glycoregulation some research questions have been raised about the action of plants that we consume. Are there certain substances in plants that have functional similarities to insulin? Do the plants we eat contain such substances? Is their consumption safe, even in case of prolonged use? Can an excess of glucose in high carbohydrate meals be controlled by antihyperglycemic agents of food plants? Do plants inhibit elevation of blood glucose concentration sustained abnormally by hyperglycemic hormones? Can some damages such as beta cell destruction and insulin resistance be corrected by phytotherapy using food plants? In an attempt to address some of these important research questions, the overarching goal of this study was to evaluate the potential role of food plants in the prevention and treatment of diabetes in rural areas of Cameroon.

\section{MATERIALS AND METHODS}

An ethnomedical and ethnopharmacological survey was conducted to identify food plants used by diabetic patients for self-medication and to determine their role in the prevention and treatment of diabetes in Cameroon. The survey questionnaire was administered to 1131 randomly selected participants belonging to 58 socio-cultural groups, distributed all over Cameroon territory divided in three big phytogeographic regions that include coastal rain forests in which lived 293 interviewees distributed in 16 socio-cultural groups; continental rain forests in which lived 277 interviewees, distributed in 14 socio-cultural groups and SudanoZambezian and Guinian savannahs in which lived 561 interviewees, distributed in 23 sociocultural groups. Each of these regions was divided into phytogeographic units [4, 5]. Included in this study were interviewees who were either local therapists treating family members suffering from diabetes or food plants users in families with someone affected by diabetes or were diabetic patients on treatment. Finally, some other interviewees among 1131 gave complementary useful information such as good ethno-pharmacological detailed preparation, vernacular names of food plants, side and undesirable effects, useful advices were also involved in the study. Each diabetic patient included in this study was treated by familial selfmedication using a food plant and all the interviewees are presented in. table 1.

Table 1: Distribution of interviewees

\begin{tabular}{cccc}
\hline $\begin{array}{c}\text { Phytogeographic } \\
\text { areas }\end{array}$ & $\begin{array}{c}\text { Number of } \\
\text { interviewees }\end{array}$ & $\begin{array}{c}\text { Number of } \\
\text { socio-cultural groups }\end{array}$ & $\begin{array}{c}\text { Number of } \\
\text { patients treated in } \\
\text { family by self- } \\
\text { medication }\end{array}$ \\
\hline Area 1 & 293 & 18 & 30 \\
Area 2 & 277 & 15 & 34 \\
Area 3 & 561 & 25 & 36 \\
Total & 1131 & 58 & 100 \\
\hline
\end{tabular}


A review of the medical records of the people interviewed indicated, that a total of 100 participants were diabetic patients. They were further divided into two groups. Group 1 was constituted of 42 diabetic patients who regularly consume certain food plants, and Group 2 included 58 people who were town dwellers and did not regularly eat the identified food plants. It was also determined from the medical records of fasting blood glucose and hospitalization rate, that the time of onset of diabetes was around 45 years for Group 1 patients and about 70 years in Group 2. Also, in Group 2, ten patients were clearly identified as type 1 diabetic patients. Meanwhile, forty-one patients from Group 1 were clearly diagnosed as type 2 diabetic patents. The admitted diabetic patients in this study signed the informed consent and accepted that we proceeded to the evaluation of the effectiveness of food plants usually used for family self-medication. The results were spread throughout the population to enable the knowledge and use of the most effective recorded plants with regard of the type of diabetes. The food plants consumed by diabetic patients were identified and confirmed at the National Herbarium of Cameroon where the plant samples were deposited. Also, detailed information was provided on the type of plant material used, the method of medicinal formulation, the preparation duration, the volume of solvent, the recommended daily dosage and the duration of treatment.

\section{RESULTS}

Ten food plant species belonging to 10 genera from 10 families were reported to be used in the preparation of the herbal remedies. Diabetic patients recorded among the 1131 interviewees were divided into two groups. Group 1 was constituted of 42 diabetic patients who regularly consumed certain food plants and started presenting diabetic symptoms or complications at around 70 years. The second group was made up of 58 people who were town-dwellers and did not eat the identified food plants regularly. The onset of their diabetes was around 45 years. The ethnopharmacological detailed preparation of recipes, their route of administration and the posology are described in Table 2.

Table 2: Antihyperglycemic herbal medicines derived from special foods

\begin{tabular}{llll}
\hline $\begin{array}{l}\text { Scientific names of plants, family } \\
\text { and identified antihyperglycemic } \\
\text { compounds }\end{array}$ & $\begin{array}{l}\text { Traditional special } \\
\text { food's preparation, } \\
\text { Vernacular names and } \\
\text { dialects, and/or } \\
\text { common names and } \\
\text { languages }\end{array}$ & $\begin{array}{l}\text { Preparation of recipes } \\
\text { derived from } \\
\text { traditional special } \\
\text { diets }\end{array}$ & $\begin{array}{l}\text { Number and } \\
\text { group of } \\
\text { diabetics who } \\
\text { used the } \\
\text { recipes }\end{array}$ \\
& & &
\end{tabular}

\begin{tabular}{|c|c|c|c|c|}
\hline & & & GD1 & GD2 \\
\hline \multirow[t]{2}{*}{$\begin{array}{l}\text { 1-Solanum melongena } \mathrm{L} . \\
\text { (Solanaceae), Trigonnelline } \\
\text { 2- Allium cepa } \text { L. (Alliaceae) }\end{array}$} & $\begin{array}{l}\text { Drink the decoction of } \\
\text { fruits called Medip-zon } \\
\text { in Beti tribes } \\
\text { Fruits:condiment of } \\
\text { yellow soup in Bamileke } \\
\text { tribe Edible fruit in many } \\
\text { tribes in Adamaoua, } \\
\text { North and Far North } \\
\text { regions }\end{array}$ & $\begin{array}{l}\text { Boil } 10 \text { garden eggs in } 3 \\
\text { liters of water with little } \\
\text { quantity of pepper. } \\
\text { Filter and drink } 250 \mathrm{ml} \\
\text { of decoction } 3 \text { times per } \\
\text { day for } 10 \text { days }\end{array}$ & 7 & 12 \\
\hline & $\begin{array}{l}\text { Cheuche 'eu (Yemba) } \\
\text { Aubergine (Français), } \\
\text { Garden egg (English) }\end{array}$ & $\begin{array}{l}\text { Eat } 3 \text { garden eggs per } \\
\text { day }\end{array}$ & 4 & 8 \\
\hline
\end{tabular}




\begin{tabular}{|c|c|c|c|c|}
\hline \multirow[t]{2}{*}{$\begin{array}{l}\text { Scientific names of plants, family } \\
\text { and identified antihyperglycemic } \\
\text { compounds }\end{array}$} & \multirow[t]{2}{*}{$\begin{array}{l}\text { Traditional special } \\
\text { food's preparation, } \\
\text { Vernacular names and } \\
\text { dialects, and/or } \\
\text { common names and } \\
\text { languages }\end{array}$} & \multirow[t]{2}{*}{$\begin{array}{l}\text { Preparation of recipes } \\
\text { derived from } \\
\text { traditional special } \\
\text { diets }\end{array}$} & \multicolumn{2}{|c|}{$\begin{array}{l}\text { Number and } \\
\text { group of } \\
\text { diabetics who } \\
\text { used the } \\
\text { recipes }\end{array}$} \\
\hline & & & GD1 & GD2 \\
\hline & & $\begin{array}{l}\text { Add } 10 \text { garden eggs in } \\
3 \text { liters of yellow soup } \\
\text { and take } 1 / 2 \text { liter per day } \\
\text { for } 10 \text { days }\end{array}$ & 5 & 3 \\
\hline & Onion: condiment & $\begin{array}{l}\text { Pound } 1 \mathrm{~kg} \text { of Onion } \\
\text { and } 1 \mathrm{~kg} \text { of Garlic }\end{array}$ & 4 & 3 \\
\hline $\begin{array}{l}\text { 3-Allium sativum L. (Alliaceae) } \\
\text { Alliine hypoglycemic } \\
\text { allyl propyl disulfide (APDS) }\end{array}$ & Garlic: condiment & $\begin{array}{l}\text { together. Boil in } 5 \text { liters } \\
\text { of water. Drink a glass } \\
\text { of } 250 \mathrm{ml} \text { three times } \\
\text { daily for a week. This } \\
\text { treatment is more } \\
\text { effective than the } \\
\text { treatments using Garlic } \\
\text { or Onion solitary. }\end{array}$ & 3 & 2 \\
\hline $\begin{array}{l}\text { 4-Momordica charantia L. } \\
\text { (Curcubitaceae) charantine, } \\
\text { momordicine, foetidine ou } \beta \text { - } \\
\text { sitostérol }\end{array}$ & $\begin{array}{l}\text { Leaflet stems vegetable } \\
\text { Lepohkenang } \\
\text { Margot } \\
\text { Bitter melon, karela, } \\
\text { balsam pear, or bitter } \\
\text { gourd }\end{array}$ & $\begin{array}{l}\text { Cut into small pieces } \\
300 \mathrm{~g} \text { of aerial parts of } \\
\text { Momordica charantia L. } \\
\text { (leaflet stems, } \\
\text { flowers and fruits). Boil } \\
\text { in } 3 \text { liters and drink } 250 \\
\text { ml of decoction three } \\
\text { times daily }\end{array}$ & 4 & 12 \\
\hline $\begin{array}{l}\text { 5-Adansonia digitata } \mathrm{L} \text {. } \\
\text { (Bombacaceae) }\end{array}$ & $\begin{array}{l}\text { Consumption of fruit } \\
\text { pulp } \cdot \text { Soup of pound } \\
\text { leaves of Adansonia } \\
\text { digitate }\end{array}$ & $\begin{array}{l}\text { Consume of } 100 \mathrm{~g} \text { of } \\
\text { fruit pulp three times } \\
\text { daily. Pound the leaves. } \\
\text { Boil } 20 \mathrm{~g} \text { of powder in } \\
300 \mathrm{ml} \text { of water and } \\
\text { drink morning, midday } \\
\text { and Evening regularly }\end{array}$ & 4 & 3 \\
\hline $\begin{array}{l}\text { 6-Asystagia gangetica (L.) T. } \\
\text { Anderson. (Acanthaceae) }\end{array}$ & Leaves vegetable & $\begin{array}{l}\text { Boil } 500 \mathrm{~g} \text { of leaves in } \\
4 \text { liters of water. Drink } \\
250 \mathrm{ml} \text { three times per } \\
\text { day }\end{array}$ & 4 & 1 \\
\hline $\begin{array}{l}\text { 7-Pourpartia birrea A.Rich.) } \\
\text { Hochst. (Anacardiaceae) }\end{array}$ & $\begin{array}{l}\text { Leaves vegetable in } \\
\text { soup, stem bark root } \\
\text { and fruits edible, young } \\
\text { leaves in salad dishes }\end{array}$ & $\begin{array}{l}\text { Pound dry leaves. Put } \\
20 \mathrm{~g} \text { of powder in } 250 \\
\mathrm{ml} \text { of water, filter then } \\
\text { drinks four times daily. }\end{array}$ & 1 & 5 \\
\hline $\begin{array}{l}\text { 8-Brassilia oleracea } \mathrm{L} . \\
\text { (Brassicaceae) }\end{array}$ & $\begin{array}{l}\text { Leaves vegetable is a } \\
\text { popular dietary eaten all } \\
\text { over the world in soup } \\
\text { or raw in a salad. }\end{array}$ & $\begin{array}{l}\text { Pound the leaves and } \\
\text { extract juice. Drink a } \\
\text { glass of } 250 \mathrm{ml} \text { three } \\
\text { times a day. }\end{array}$ & 2 & 3 \\
\hline $\begin{array}{l}\text { 9-Ipomoa batatas L. } \\
\text { (Convolvulaceae) }\end{array}$ & $\begin{array}{l}\text { Leaves vegetable in } \\
\text { soup }\end{array}$ & $\begin{array}{l}\text { Boil } 300 \mathrm{~g} \text { of leaves in } \\
3 \text { liters of water and } \\
\text { drink } 250 \mathrm{ml} \text { of } \\
\text { decoction three times } \\
\text { daily }\end{array}$ & 3 & 3 \\
\hline & & & 1 & 3 \\
\hline
\end{tabular}




\begin{tabular}{lll}
\hline $\begin{array}{l}\text { 10-Allanblackia floribunda Oliv. } \\
\text { (Clusiaceae) }\end{array}$ & $\begin{array}{l}\text { Food preparation with } \\
\text { fat extracted from the } \\
\text { seed, called } \\
\text { 'allanblackia fat' or } \\
\text { 'beurre de bouandjo' }\end{array}$ & $\begin{array}{l}\text { Pound the seeds. Put 20 } \\
\text { gof powder in 250 ml } \\
\text { of water. Filter and } \\
\text { drink the macerate three } \\
\text { times daily }\end{array}$ \\
$\begin{array}{l}\text { Noms locaux. Badjoué: ntia; Bassa: nyonne; } \\
\begin{array}{l}\text { Bobili: } \\
\text { damngozé; Boulou : anyoé, anjek; Douala: } \\
\text { eboungomatatolo; Ewondo : nsangomo; Ibo } \\
\text { egba; Maka : mwinch }\end{array}\end{array}$ & $\begin{array}{l}\text { Seeds eaten in times of } \\
\text { food scarcity }\end{array}$ & \\
\end{tabular}

GD1: Group of diabetic patients showing a disease onset around the age of 70 years; GD2: Group of diabetic patients showing a disease onset before the age of 45 years

\section{More important food plants recorded}

Table 1 shows that the most popular plant is Solanum melongena L. used by 16 diabetes patients from Group 1 and 33 from Group 2, followed by Momordica charantia L. used by 4 patients in Group 1 and 12 patients in Group 2, and by the simultaneous use of Onion and Garlic by 7 patients in Group 1 and 5 patients in Group 2. Solanum melongena L. is cultivated in all regions and for this reason, it is abundant, available each season, and sold at various marketplaces and well known by people.

\section{Types of diabetes treated}

All patients were successfully treated using herbal medicines. Ten patients with type- 1 and 41 patients with type-2 diabetes diagnosed by a local physician were effectively treated using Momordica charantia L. The consumed food plants may act in a similar way to injectable insulin or to oral hypoglycemic drugs. For a good management of diabetes using food plants, patients must know their diagnostic status and the types of food plants to use. Type 1 diabetes patients should use plants that act by mimicking the effect of human insulin, while type 2 diabetes patients should use mainly food plants that promote pancreatic action.

\section{DISCUSSION}

\section{Prevention and treatment of diabetes}

The anti-diabetic uses of recorded food plants have been confirmed by modern scientific evidence except for Allanblackia floribunda Oliv. Plants can prevent and delay the onset of diabetes [20]. These results demonstrate that food plants, because of their therapeutic propertiesand low toxicity, helped diabetic patients for a considerable amount of time without substantial side effect. Antihyperglycemic compounds of these plants did not lower the glucose concentrations below the normal/acceptable glycemic levels. Indeed, none of the patients manifested hypoglycemia during their follow-up period. Hence, the management of diabetes by the use of food plants may be highly recommended in rural communities of Cameroon. Many of these plants are very rich in bioactive antihyperglycemic compounds that react in synergy with other substances to the signs and symptoms and improve the health of diabetes patients. However, the antihyperglycemic mechanisms of many of these bioactive compounds remain uncertain, and additional investigations are required to clarify their modes of action [21-22].

Investigation of the ethnomedical uses of Momordica charantia L. worldwide revealed that this plant is one of the most important species for controlling hyperglycemia in diabetic patients [23].

The $M$. charantia $L$. extracts and their isolated compounds exert antihyperglycemic activities through diverse biochemical and physiological processes. These processes mainly include the induction of insulin production, stimulation of skeletal muscle and peripheral cell 
glucose combustion, inhibition of intestinal glucose absorption, inhibition of adipocyte differentiation, suppression of key gluconeogenic enzymes, stimulation of enzymes of the hexose monophosphate pathway and pancreatic islet cells and preservation of their functions

[23]. Polypeptide-p or p-insulin is an insulin-like hypoglycemic protein that decreases the blood glucose levels in diabetic patients, after subcutaneous injection [20]. This p-insulin works by mimicking the effect of human insulin. Therefore, it may be used as plant-based insulin that plays the role of normal insulin in type-1 diabetic patients [5]. The oral intake of the extract of Momordica charantia L. seeds decreases glucose levels in streptozotocininduced type-1 diabetic rats [20]. This indicates that other compounds isolated from the seeds of this herb different from p-insulin are also effective in the management of type-1 diabetes. Momordica charantia L. contains several antihyperglycemic compounds including charantin, momordicin, foetidin or $\beta$-sitostérol, polypeptide-p (protein), vicine and cucurbitane triterpenoids. These active ingredients are proven to have antihyperglycemic effects. They play an important role in the natural control of hyperglycemia in people who eat this vegetable or absorb it from herbal medicines [23]. Momordica charantia L. is a plant-based anti-diabetic medicine, used cost-efficiently worldwide to manage type 1 and type 2 diabetes. It is a rare plant available in nature that is used successfully by diabetic patients in many developing countries [24].

Allium cepa $\mathrm{L}$. and Allium sativum L. are food sources containing trigonelline which is an anti-hyperglycemic alkaloid. The effect of these two plants is reinforced by other common food plants containing trigonelline including corn, soybeans, peas, and tomatoes. Indeed, these foods are very rich in niacin. About 5 percent of this vitamin intake is converted to trigonelline. All these foods are very often eaten in one dish [25]. Experimental and clinical evidence suggests that Allium cepa L.contains allyl propyl disulfide (APDS) which is the active compound. APDS has been shown to block the breakdown of insulin by the liver, to stimulate insulin production by the islet cells of the pancreas and to increase the amount of insulin which reduces blood glucose levels [25]. Daily treatment of rats for Streptozotocin (STZ)-induced diabetes by the intraperitoneal administration of $500 \mathrm{mg} / \mathrm{kg}$ of raw Allium cepa L. extract during seven weeks significantly lowered blood glucose, cholesterol and triglyceride levels. In comparison with control diabetic rats, Allium cepa L. -treated rats presented 57\% lower serum glucose, $40 \%$ less serum cholesterol and $35 \%$ fewer triglyceride levels.

Furthermore, urinary protein level in Allium cepa L.-treated diabetic rats were 50\% less in comparison with diabetic control rats. In contrast, the increased urine output and water intake of diabetic rats were not affected by Allium cepa L. diabetics control. These results show that raw Allium серa L. presents a beneficial effect, probably reversing proteinuria in addition to decreasing blood glucose, serum cholesterol and serum triglycerides in diabetic rats. Consequently, Allium cepa L. could be of great value in the management of the effects and the complications of diabetes in affected people [26].

The pulp of Adansonia digitata L. is rich in flavonoids and conjugated flavonoids such as Quercetin-3Glycosides that tend to inhibit $\mathrm{Na}^{+}$and the unsaturated absorption of glucose by the intestinal sodium-glucose transporter-1. Flavonoids and glycosides also stimulate insulin secretion in $\beta$ cells of the pancreas. In addition, flavonoids inhibit the activity of glucose-6phosphatase in the liver. Thereby the suppression of gluconeogenesis and glycogenolysis 
reduces hyperglycemia. Many reports of herbal remedies for diabetes show that flavonoids have antioxidant properties. This suggests that the fruit pulp extract of Adansonia digitata $\mathrm{L}$. has antidiabetic effect in humans [27].

Brassica oleracea L. var. Italica ethanolic extract demonstrated hypoglycemic effects in Health Food Drink-Streptozotocin-type 2 diabetic rats after four weeks of treatment [28]. Brassica oleracea L. is one of the rare vegetables that reduce the blood glucose levels and are commonly eaten in the world. This vegetable has shown beneficial hypoglycemic activity both in laboratory animals and humans [29]. It is a plant that improves insulin resistance in type 2 diabetes and reduces its complications. This is a new approach that consists of the use of its antioxidant and anti-inflammatory flavonoids effects to control complications and to protect against diabetes [30]. Brassica oleracea L. is the only easily accessible vegetable that contains significant amounts of glucoraphanin, a substance converted in the plant to sulforaphane by an enzyme, myrosinase. Sulforaphane is very interesting for its amazing effects of potentially inducing some peroxisome proliferator-activated receptors that promote glucose homeostasis under hyperglycemia and oxidation influences. This substance also prevents nephropathy, induced-diabetes fibrosis, and cardiovascular complications. It is an excellent choice for the complementary treatment of type 2 diabetes [31].

The qualitative phytochemical study of Ipomoea batatas L. showed the presence of alkaloids, flavonoids, tannins, saponins, steroids, phenol, anthraquinone, phlobatinne, glycosides and terpenoids. The quantitative phytochemical study revealed that saponin (16, 30) was richest among photochemical (4.05), tannin (4.05) followed, and glycoside (0.29) was the least. The dose of $200 \mathrm{mg} / \mathrm{kg} /$ day of the extract showed the best hypoglycemic activity $(69.35 \%)$ in rats with induced diabetes [32].

Treatment with Sclerocarya birrea (A. Rich.) Hochst. improves glucose homeostasis in streptozotocin-induced diabetes by stimulating insulin secretion. Thus, the in vivo study realized by Dimo and his colleagues in Cameroon revealed that the methanol/methylene chloride extract of Sclerocarya birrea (A. Rich.) Hochst stem bark showed a significant reduction in blood glucose and an increase in plasma levels of insulin in rats with induceddiabetes. Oil, protein and phenol compounds are isolated from leaves and bark, while the fruit is rich in ascorbic acid and the juice of fruit contains sesquiterpene hydrocarbon. The seed contains a soft white nucleus rich in oil and protein. The oil contains oleic, palmitic, myristic, and stearic acids; and the nucleus protein contains amino acids with a predominance of glutamic acid and argentine [33].

The extract of Asistagia gangetica (L.) T. Anderson, has shown a significant decrease in plasma glucose levels with a simultaneous increase of both body weight and insulin levels. It also exerts an anti-diabetic action. This extract has shown to also have antioxidant and hypolipidemic activities and to decrease lipid peroxidation. It has also been reported that the treatment with Asistagia gangetica (L.) T. Anderson extract increases the number of islets cells and also protects the organs by reducing the oxidative stress associated to diabetes and by increasing insulin production by the regenerated $\beta$ cells [34].

\section{Additional scientific data on Momordica and other medicinal plant extracts demonstrating their efficacy on diabetic parameters.}

Manifold antihyperglycemic plants showed several demonstrated hypoglycemic properties. Some of these plants are presented in table 3. 
Table 3: Efficacy of plants on diabetic parameters

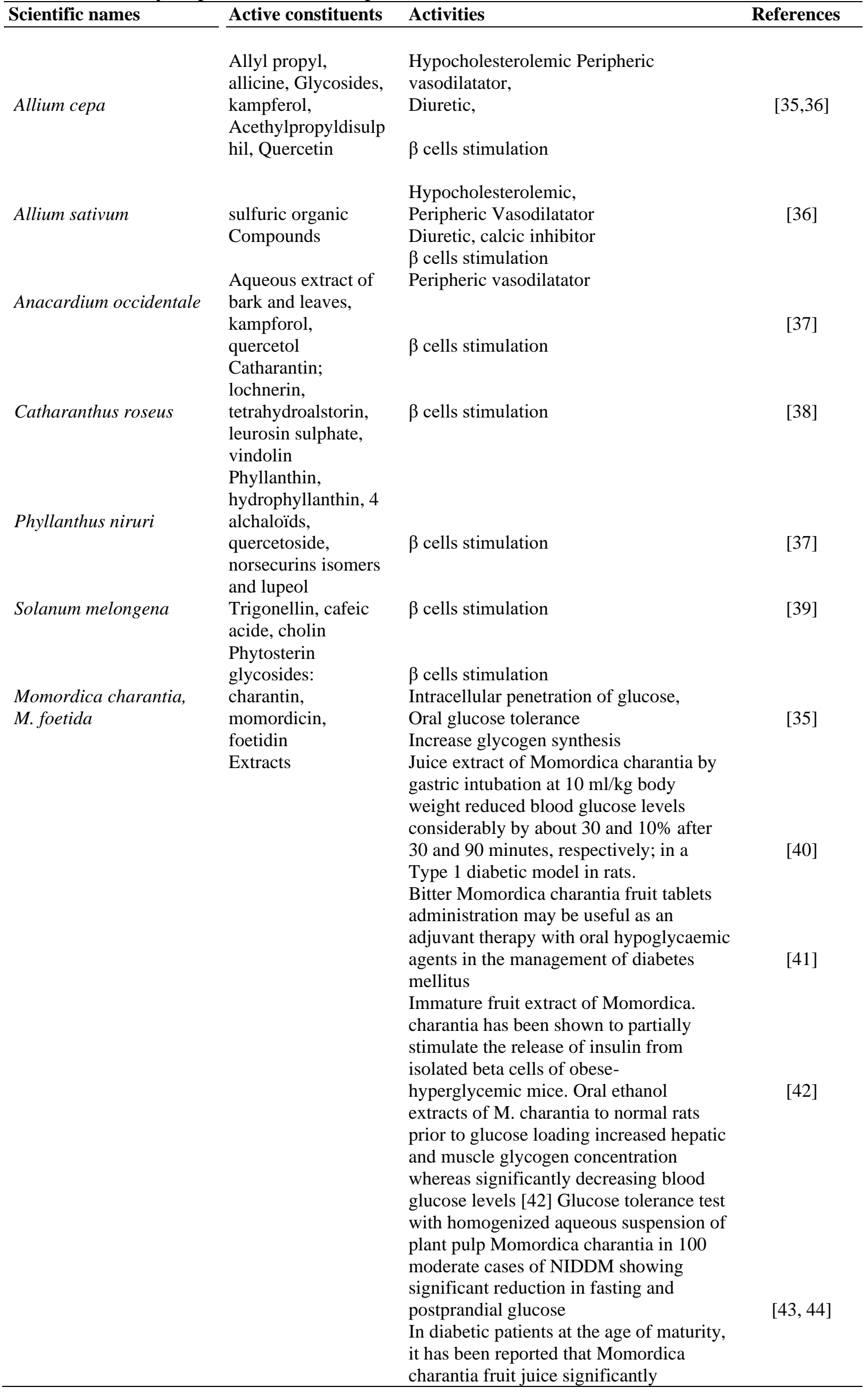


improves glucose tolerance test in the

patient population studied

Previous studies have demonstrated the efficacy of Momordica. charantia in diabetes and various cancers (lymphoid leukemia, lymphoma, choriocarcinoma, melanoma, breast cancer, skin tumor, prostatic cancer, squamous carcinoma of tongue and larynx, human bladder and Hodgkin's disease). M. charantia has been clinically used to manage diabetes and cancer patients. This treatment has shown convincing results.

Intracellular penetration of glucose

Spathodea campanulate

Aqueous extract

Sonchus oleraceus Picralima nitida
Whole plant and leave extracts
Whole plant and leaves extracts possess both antidiabetic and antioxidant properties and could be used for developing diabetic herbal medicines.

\section{SUMMARY AND CONCLUSION}

This study shows that Momordica charantia L., which has been used for many centuries in the form of food, herbal medicine, and dietary supplements in Cameroon. It is the most interesting food plant in the management of diabetes and its symptoms. It has been reported that this plant contains more than 225 different active constituents. Except for Allanblackia floribunda Oliv. which requires further chemical and pharmacological investigations to ascertain its antihyperglycemic effect, different compounds isolated from other recorded plants can act individually or together to produce their anti-diabetic effects through various biochemical mechanisms. Therefore, food plants can prevent and/or control both type 1 and type 2 diabetes and their symptoms. The importance of food plants in the prevention and treatment of diabetes are associated with their effectiveness in curing the disease. However further investigations and/or clinical trials involving a large number of both type 1 and type 2 diabetics' patients may be needed to confirm the therapeutic action of many food plants against diabetes and other metabolic diseases. In particular, food plants may be a feasible option for many developing countries that have a high prevalence of diabetes and cannot afford conventional treatment. Diabetic patients in those countries often prefer herbal medicines because of their low economic status and their cultural beliefs. The plant species identified in this study are functional foods with bioactive compounds capable to regulate hyperglycemia in diabetic patients and hence the most important may be used selectively by diabetic patients. They are also used as dietary supplements and/or interventions to prevent/control diabetes and improve the health of patients.

Competing interests: Professor Paul Bernard Tchounwo and Associate Professor Clement Yedjou are my collaborators in the United States of America. They have read the manuscript and approved it. All the field work was carried out in Cameroon. So, there are no competing interests that can oppose the publication of this manuscript.

Authors' contributions: Tsabang Nole contributed from the conception, field work to the final draft of the manuscript. Lionel W. Tsambang Djeufack contributed to the field work. Prof. 
Paul B. Tchounwo and Prof. Clement Yedjou read and review the manuscript. All authors have read and approved the final manuscript.

Acknowledgments and funding: We are grateful and thankful for the local therapists and householders at various field locations who participated and contributed to the successful implementation of this research. We also express thanks to Bioresources Development and Conservation Programme-Cameroon (BDCP-C) for the training courses that we received on the field ethnobiology, and to late Professor Koueke Paul, Ex. Professor of Faculty of Medicine and Biomedical Sciences, University of Yaoundé for his precious supervision of this work. We acknowledged partial support for co-authors Prof. Paul B. Tchounwo and Prof. Clement Yedjou from NIH, Grant \# G12MD007581.

\section{REFERENCES:}

1. Steyn NP, Mann J, Bennett PH, Temple N, Zimmet P, Tuomilehto J, Lindstrom J and Louheranta A. Diet, nutrition and the prevention of type 2 diabetes. Public Health Nutrition, 2004, 7(1A):147-165.

2. Mbanya JC, Ngogang J, Salah JN, Minkoulou E and Balkau B. Prevalence of NIDD and impaired glucose tolerance in a rural and an urban population in Cameroon. Diabetologia, 1997, 40:824-829.

3. Justin B Echouffo-Tcheugui and Andre P Kengne. Chronic non-communicable diseases in Cameroon - burden, determinants and current policies. Global Health, 2011, 7: 44.

4. Tsabang Nolé and Tsambang DW L. A Different Approach in the Traditional Treatment of Diabetes and of Antidiabetic Plants Discovery in Cameroon. Glob J Pharmaceu Sci, 2017, Volume 3 Issue 4: 1-5

5. Tsabang N, Ngah N, Estella FT, Agbor GA. Herbal Medicine and Treatment of Diabetes in Africa: Case Study in Cameroon. Diabetes Case Rep., 2016, 1:112

6. Burchi F, Fanzo J, Frison E. The role of food and nutrition system approaches in tackling, Hidden hunger. Int. J. of environmental Research and Public Health, 2011, 8:358-373.

7. Darnaud C. Que sais-je ? Le point de connaissances actuelles sur le diabète. Presse. Universitaire de France, 1959, Pp.126.

8. Zemin Cao and Mark E Cooper. Pathogenesis of diabetic nephropathy. Journal of diabetes investigation,2011, 2 (4): 243-247.

9. Behradmanesh S, Nasri P. Serum cholesterol and LDL-C in association with level of diastolic blood pressure in type 2 diabetic patients. J Renal Inj Prev. 2012, 1: 236.

10. Chang E, Donkin SS, Teegarden D. Parathyroid hormone suppresses insulin signaling in adipocytes. Mol Cell Endocrinol. 2009; 307:77-82.

11. Mardani S, Nasri H, Rafieian-Kopaei M, Beladi Mousavi SS. Hyperuricemia; a new look at an old problem. J Nephropharmacol. 2012; 1:13-4. 
12. Momeni A. Serum uric acid and diabetic nephropathy. J Renal Inj Prev. 2012; $1: 37-8$.

13. Kalantar Zadeh K. A Critical Evaluation of Glycated Protein Parameters in Advanced Nephropathy: A Matter of Life or Death: A1C remains the gold standard outcome predictor in diabetic dialysis patients. Counterpoint. Diabetes Care. 2012,35:1625-8.

14. McMurray SD, Johnson G, Davis S, McDougall K. Diabetes education and care management significantly improve patient outcomes in the dialysis unit. Am J Kidney Dis. 2002; 40:566-75.

15. Stanton RC. Oxidative stress and diabetic kidney disease. Curr Diab Rep. 2011; $11: 330-6$.

16. Darnaud C. (1959). Que sais-je ? Le point de connaissances actuelles sur le diabète. Presse Universitaire de France, 126 p.

17. Upjohn Diabetes, a monograph on diabetes millitus. Upjohn Company. Kalamazoo, Michigan, 1963, Pp.260.

18. Tsabang N. (2008), Etude ethnobotanique des plantes à vertus antidiabetiques et/et antihypertensives au Cameroun. Thèse de Doctorat/PhD. Université de Yaoundé I, $318 \mathrm{p}$.

19. Letouzey R. Carte phytogéographique et notice. Int. Cart. Internat. Végétation, Toulouse. 1985, 240 p.

20. Letouzey R. Carte phytogéographique et notice. Int. Cart. Internat. Végétation, Toulouse. 1985, 240 p.

21. Paul A, Raychaudhuri SS. (2010) Medicinal uses and molecular identification of two Momordica charantia varieties - a review. E J Bio, 6(2):43-51.

22. Tayyab F, Lal SS, Mishra M, Kumar U. A review: Medicinal plants and its impact on diabetes. World J Pharm Res. 2012, 1(4):1019-1046.

23. Prakash O, Kumar R, Srivastava R, Tripathi P, Shradha M. Ajeet Plants Explored with antidiabetic Properties. A Review. American Journal of Pharmacological Sciences, 2015, 3(3):55-66.

24. OueslatiK HA, Ghédira K Notes ethnobotanique et phytopharmacologique sur Trigonella foenum-graecum. Phototherapy. 2015, Volume 13(4), 4234-238.

25. Wehash FE, Abpo-Ghanema II, Saleh RM. Some physiological effects of Momordica charantia and Trigonella foenum-graecum extracts in diabetic rats as compared with cidophage. World Academy of Science, Engineering and Technology, 2012, 64:1206- 1214.

26. Baby J. and Jini D. Antidiabetic effects of Momordica charantia (bitter melon) and its medicinal potency. Asian Pac J Trop Dis., 2013, 3(2):93-102.

27. Thomson M, Zainab M, Al-Amin, Khaled K, Al-Qattan, Lemia HS and Muslim A anti-diabetic and hypolipidaemic properties of garlic (Allium sativum) in streptozotocin-induced diabetic rats Int J Diabetes \& Metabolism. 2007; 15:108-115. 2015, 3(3):55-66. 
28. Mohammad Yalwa Gwarzo and Hauwa'uYakubu Bako. Nigeria Hypoglycemic Activity of Methanolic Fruit Pulp Extract of Adansonia digitata on Blood Glucose Levels Alloxan Induced Diabetic Rats. International Journal of Animal and Veterinary Advances, 2013, 5(3):108-113

29. Shah MA, Sarker MMR, Gousuddin M. Antidiabetic Potential of Brassica Var. Italica in Type 2 Diabetic Sprague Dawley (sd) Rats. International Journal of Pharmacognosy and Phytochemical, 2016, 8(3):462-469

30. Walum E. Acute oral toxicity. Environmental health perspectives, 1998,106 (2):497

31. Masiello P, Broca, C., Gross, R., Roye, M. Manteghetti, M., Buys H, Novelli M.and Ribes G. Experimental NIDDM: development of a new model in adult rats administered Streptozotocinand Nicotinamide. Diabetes Technol, 1998, 47:224-9.

32. Sd Haseeb J and Sunitha M. (2017) Study of Ipomoea batatas L. extracts for antidiabetic activity. European Journal of Pharmaceutical and Medical Research, 2017, 4(7):671-677.

33. . Abdalbasit A M and Siddig IA. Sclerocarya birrea: Biochemical Composition, Nutritional and Medicinal Uses-A Review. Natural Products: Research Reviews.2017, 1 (4): 99-120

34. Kavitha S, Rajeshwari S, Ravi D. Antidiabetic Activity of Aistasia gangetica (L.) T. Anderson flower extract in streptozotocin induced diabetes rats. IntJPharmSci., 2016, 8(8):79-84.

35. Bep O. B. (1986). Medicinal plants in Tropical West-Africa. Cambridge University Press.Cambridge, New - York, new - Rome Bourne, Sedneychelle, 375 p.

36. CIPCRE (2000). Connaissez-vous les plantes Médicinales ? Rapport de recherche. Cercle International pour la Promotion de la création (CIPCRE). ONG, Bafoussam $2 \mathrm{p}$.

37. Pousset J. L., (1989). Plantes Médicinales Africaines. Utilisation pratique. TOME I.Ellipses, Edition Marketing, Paris, 170 p.

38. Abayomi Sofowara (1986). Plantes médicinales et médecine traditionnelle d'Afrique. Traduit par Felicitas cepleanu, Académie Suisse des Sciences Naturelles, 22 (4) : 23, 289 p.

39. Paris R. R. et MOYSE H. (1971). Précis de matières médicales : collection de précis de pharmacie, Pharmacognosie spéciale, dicotylédone (suite) gamopétales. Masson et Cie. Editeurs Paris Vie. Tome 3: 509 p.

40. Mohammed Auwal Ibrahim, Md. Shahidul Islam. African Medicinal Plants with Antidiabetic Potentials: A Review. Planta Med, 2014, 80: 354-377

41. 41.Izharul Hasan and Shabnam Khatoon. Effect of momordica charantia (bitter gourd) tablets in diabetes mellitus: Type 1 and Type 2. Preme Rsearch Medicine, 2012, 2(2):72- 74.

42. Javed Ahamad, Saima Amin and Showkat R. Mir. Momordica charantia Linn. (Cucurbitaceae): Review on phytochemistry and pharmacology. Res. J. Phytochem. 2017, 11: 53-65. 
43. Welihinda J.et al., J. Ethanopharmacol.,1986:17 :277282.

44. Akthar MS.et al., J. Pak. Med Assoc.,1982:32:106107.

45. GroverJ.K.,Yadav S.P.Pharmacological actions and potential uses of Momordica charantia: a review. Journal of Ethnopharmacology 93 (2004) 123-132.

46. Niyonzima G., Scarpé S., Van Beeck L., Vlietinck A. J., Laekeman G. M. and Metz T. (1993). Hypoglycaemic activity of Spathodea campanulata stem bark decoction in mice. Phytotherapy research, 7: 64-67.

47. Clautilde Mofor Teugwa, Pascaline Chouadeu Mejiato, Denis Zofou, Bruno Tugnoua Tchinda Nand Fabrice Fekam Boyom. Antioxidant and antidiabetic profiles of two African medicinal plants: Picralima nitida (Apocynaceae) and Sonchus oleraceus (Asteraceae). Complementary and Alternative Medicine. 2013,13:175,1. 